\title{
DFT Study for Cage-annulated $p$-tert-Butylcalix[4]crown-ether Complexed with Potassium Ion
}

\author{
Kwangho Kim, Seong Jun Park, and Jong-In Choe

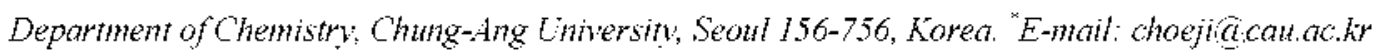 \\ Received February 17, 2008
}

\begin{abstract}
Using DFT B3LYP/6-31+G(d.p)/B3LYP/6-3IG(d.p) calculation method stable molecular structures were optimized for the p-tert-butylcalix[4]arene functionalized at lower rim by cage-anmulated crown ether (1) in two different conformers and their potassium-ion complexes. Cone conformer of free host 1 was slightly more stable than partial-cone confonmer. For two different kinds of complexation mode, the potassium ion in benzene-rings $(b z)$ pocket showed comparable complexation efficiency with the cation in cage-anmulated crown-ether $(c r)$ for the cone and partial-cone conformers of 1 . The complex $\left(1 * \mathrm{~K}^{-}\right)$in the $c r$-binding mode for the partial-cone conformer was more stable than the cone confonmer for B3LYP/6-31G(d.p) geometry optimization. However. $\mathbf{1}_{\text {(cone }}{ }^{*} \mathrm{~K}^{-}(c r)$ showed lower single-point energy than the $\left.\mathbf{1}_{\mathrm{pc}}\right)^{*} \mathrm{~K}^{+}(c r)$ for B3LYP/6$31+\mathrm{G}(\mathrm{d} . \mathrm{p})$ calculation method.
\end{abstract}

Key Words : Cage-annulated calix[4]crown-ether. Complexation. Potassium cation. DFT B3LYP/6-31G(d.p)

\section{Introduction}

Numerous calix[4]arene-based receptors have been investigated via 'upper' and 'lower' rim functionalization. 'The complexation properties of these molecules appear to be highly dependent upon the nature and number of donor atoms and the conformation of the calix[4]arene moiety.

The selective 1.3-dialkylation of p-tert-butylcalix[4]arene followed by the introduction of suitable polyether bridges on the two remaining $\mathrm{OH}$ groups has generated a new family of potassium selective ionophores. ${ }^{3}$ In particular the 1.3dimethyl ether of $p$-tert-butylcalix[4]crown-5-ether (1) has shown a surprisingly high $\mathrm{K}^{-} / \mathrm{Na}^{+}$selectivity in extraction. ${ }^{4}$

We have undertaken the relative binding affinity study of cone-shaped p-tert-butylcalix[4]aryl esters toward alkali metal cations focusing on the binding site of upper or lowerrim pocket of the host molecule using $D F T$ calculation method: The B3LYP/6-31G(d) calculation suggested that exo-complexation efficiency of potassium ion inside the cavity of lower rim of p-fert-butylcalix[4]aryl esters was better than the endo-complexation inside the upper rim (four aromatic rings). We have also reported the relative stabilities and the calculated structures of three different (cone. partial cone, and 1.3-altemate) conformers for the 1.3-dialkyl ether of p-fert-butylcalix[4]crown-5-ether (3 and 4) and their potassium-cation complexes using the B3LYP/6-31G(d.p) calculation method. ${ }^{6.7}$

Alkali metal picrate extraction studies of $p$-tert-buty lcalix[4]arene crown ether bridged at the lower rim with pyridyl unit (2) shows peak selectivity toward $\mathrm{K}^{+}{ }^{8}$ Relative complexation efficiencies of the various kinds of potassium complexes $\left(2 \cdot \mathrm{K}^{-}\right)$and the characteristics of cation-oxygen (nitrogen) and cation- $\pi$ interactions ${ }^{9}$ were calculated by $D F T$ method. ${ }^{\text {la }}$

The objectives of this research are to determine the relative stability of two different conformational isomers for



Scheme 1. Chemical drawing of the p-tert-butylcalis[4]arene functionalized at lower rim by cage-annulated crown ether (1).

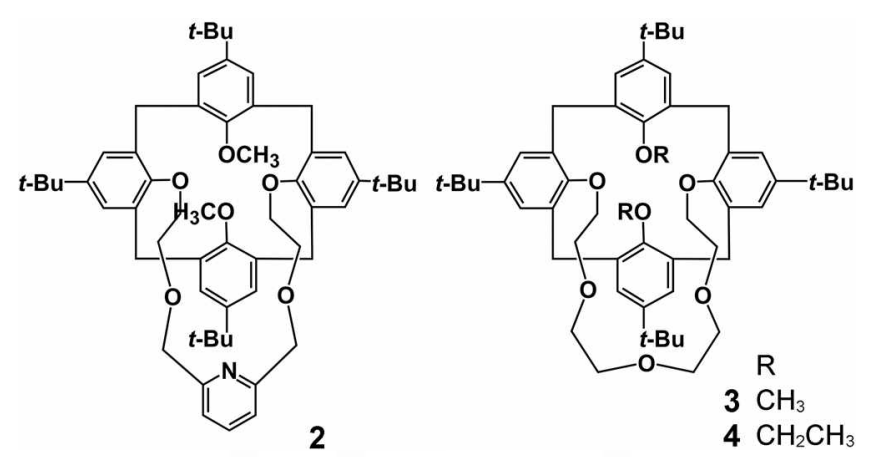

Scheme 2. Chemical drawings of $p$-ten-buty lcalix[4]crown ethers. p-ten-butylcalis[4]crown-ether bridged at the lower rum with pyndyl unit (2), 1,3-dmethyl ether of $p$-tent-butylcalis[4] crown-5ether $(3)$, and 1,3 -diethyl ether of $p$-tert-butylcalix $[4]$ crown-5-ether (4).

the host (1) and to calculate the relative complexation efficiencies of the various kinds of potassium complexes $\left(1 \cdot \mathrm{K}^{-}\right)$using the DFT B3LYP/6-31+G(d.p)//B3LYP/6$31 \mathrm{G}(\mathrm{d} . \mathrm{p})$ calculation method. 


\section{Computational Methods}

The initial structures of cage-annulated $p$-ten-butylcalix[4]crown-ether (1) which contains an oxahexacyclic cage moiety were constructed by HyperChem. ${ }^{11}$ In order to find optimized structures, we executed conformational search by simulated annealing method. ${ }^{12}$ The potassium-ion complexes of 1 were fully re-optimized using DFT B3LYP/6-31G(d.p) methods to estimate the absolute and relative energies for the different complexes after seni-entirical AMl energy minimization. The DFT B3LYP/6-31+G(d,p) single-point energy calculations of the final structures of two different conformers of host 1 and their $\mathrm{K}^{-}$-complexes by Gaussian $98^{13}$ were performed to include the diffuse functions.

\section{Results and Discussion}

The DFT calculations without any constraint were carried out for the conformers of the host 1 .

Table 1 reports the B3LYP/6-31G(d.p) optimized energies of the two kinds of conformations with two different directions ( $(00=$ out-out and oi $=$ out-in) of two methoxy groups of 1 . The calculations suggest that cone_oo conformer of 1 is found to be slightly $(0.62 \mathrm{kcal} / \mathrm{mol})$ more stable than partialcone oo analogue. The oi structures of both cone and partial-cone conformers are much less stable than the oo conformations. Since 1.3-altenate conformation was not very stable due to the steric hinderance of bulky cageaninulated crown ether in the lower rim of 1 , one of two inverted p-tert-butylanisole groups spontaneously swing to the more stable partial-cone analogue during optimization. The relative stability of the conformers of 1 is different from the 1.3-dialkyl ether of p-tent-butylcalix[4]cromn-5-ether $\left(3^{6}\right.$ and $4^{7}$ ). where cone conformer is $2-6 \mathrm{kcal} / \mathrm{mol}$ more stable than partial-cone antogue.

The DFT B3LYP/6-31G(d.p) optimizations have been carried out for two kinds of complexation mode for each conformer: combining cone or partial-cone conformer of 1 with potassium ion in two different locations (the cageannulated crown-ether $(c r)$ or benzene-rings $(b z)$ pocket) of 1 .

Table 2 reports the B3LYP/6-31G(d.p) calculated complexation energies of the four different complexes in two different binding modes. When one compares the relative

Table 1. DFT B3LYP/6-31G(d,p) Calculated Energies ${ }^{2}$ of Diff̈erent Conformations of Free Host (1)

\begin{tabular}{llcc}
\hline Confonmer $^{b}$ & Figure & a.u. & $\Delta E^{c}$ \\
\hline Cone_oo & Fig. I (a) & -3054.12922 & 0.00 \\
Cone_oi & Fig. 1 (b) & -3054.11786 & 7.12 \\
Partial-cone_oo & Fig. 2 (a) & -3054.12822 & 0.62 \\
Partial-cone_oi & Fig. 2 (b) & -3054.12149 & 4.84 \\
\hline
\end{tabular}

"Error limit is 0.01 kcal mol $\left(2 \times 10^{-5}\right.$ atomic unit) for each structure. "oo means that both of the methoxy groups are pointing outward, oi denotes that one of the methoxy groups is pointing inward. ${ }^{\prime} \Delta E$ is the relatice energy (kcal mol) with respect to the most stable confonmation of the free host.
Table 2. DFT B3LYP/6-31G(d,p) Complexation Energies of Different Complexes of Host (1) with Potassium Ion

\begin{tabular}{|c|c|c|c|c|}
\hline Binding mode & Figure & $E_{\text {complex }}^{b t}$ & $\Delta E_{\text {compler }}{ }^{c}$ & $\Delta E_{r e l}{ }^{l}$ \\
\hline $1_{\text {isuttej }} \cdot \mathrm{K}^{-}(c r)$ & Fig. l(c) & -3653.95306 & -62.01 & 6.25 \\
\hline $1_{\text {isutue }} \cdot \mathrm{K}^{-}(b z)$ & Fig. I(d) & -3653.96097 & -66.98 & 1.29 \\
\hline $1_{i p o v} \cdot K^{-}(c r)$ & Fig. 2(c) & -3653.96302 & -68.26 & 0.00 \\
\hline $1_{i p j} \cdot K^{-}(b z)$ & Fig. 2(d) & -3653.95972 & -66.19 & 2.07 \\
\hline
\end{tabular}

${ }^{a} c r$ indicates crown-ether cavity binding. and $b z$ means benzene-rings pocket mode. $\mathbf{1}_{\text {icute? }}$ and $\mathbf{1}_{i p)}$ mean the cone_oo and partial-cone_oo conformations of host (1). ${ }^{b} E_{\text {ionplex }}$ (a.u.) is the total energy of the complex. " $\Delta E_{\text {complity }}(\mathrm{kcal}$ mol) is defined as the total enengy of the complex minus the sum of the total energies of the cation and the most stable free ligand (cone_oo) confonmation. ${ }^{d} \Delta E_{r e j}(\mathrm{kcal} / \mathrm{mol})$ is defined as the binding energies relative to that of the most strongly bound complex.

stabilities of the complexes for the different guest positions in Table 2, the potassium cation in the benzene-rings $(b z)$ pocket has better complexation efficiency than in the crownether moiety $(\mathrm{cr}$ ) for the cone conformation of host 1 due to the strong cation- $\pi^{\vartheta, 16}$ interactions. However. $\mathbf{1}_{(\mathrm{p}) \mathrm{c}^{*}} \mathrm{~K}^{-}(c r)$ is most stable in all four cases. and $2.07 \mathrm{kcal} / \mathrm{mol}$ more stable than the $\mathbf{1}_{\mathrm{ip} c} \cdot \mathrm{K}^{-}(b z)$ for the partial-cone conformation.

Since basis sets with diffuse functions are important for systems where electrons are relatively far from the nucleus such as molecules with lone pairs, we have performed the DFT B3LYP/6-31+G(d.p) single-point energy calculations of the final structures of different conformers of host 1 and their $\mathrm{K}^{+}$-complexes.

Table 3 reports the B $3 L Y P / 6-31+G(d, p)$ single-point energies of the various conformations of the host 1 . The calculations suggest that cone_oo conformer of 1 is found to be $2.2 \mathrm{kcal} / \mathrm{mol}$ more stable than partial-cone oo analogue. and that the oi confonmers are much less stable than the oo analogues

Table 4 reports the B3LYP/6-3I+G(d,p) calculated complexation energies of the four different complexes in two different binding modes. When one compares the relative stabilities of the complexes for the different guest positions in Table 4, the potassium cation in the benzene-rings ( $c r$ ) pocket has slightly better complexation efficiency than in the crown-ether moiety ( $b z)$ for both of the cone and partial conformations of host 1 . Cone $c r$-complex $\left(\mathbf{1}_{\text {(cone) }} \cdot \mathrm{K}^{-}(c r)\right)$ is $2.35 \mathrm{kcal} / \mathrm{mol}$ more stable than the partial-cone analogue. This result is different from the B3LYP/6-31G(d.p) optimized energies. which report that partial-cone $c r$-complex $\left(\mathbf{1}_{\mathrm{pci}} \cdot \mathrm{K}^{+}(\mathrm{Cr})\right)$ is more stable than the cone analogue. Here,

Table 3. DFT B3LYP/6-31+G(d,p) Calculated Energies of Different Conformations of Free Host (1)

\begin{tabular}{llcc}
\hline Confonmer $^{b}$ & Figure & a.u. & $\Delta E^{c}$ \\
\hline Cone_oo & Fig. l (a) & -3054.20144 & 0.00 \\
Cone_oi & Fig. l (b) & -3054.19002 & 7.17 \\
Partial-cone_oo & Fig. 2 (a) & -3054.19823 & 2.02 \\
Partial-cone_oi & Fig. 2 (b) & -3054.19157 & 6.19 \\
\hline
\end{tabular}

${ }^{a}$ Single-point energy calculations at the DFT B3L.YP:6-3I-G(d.p) level based on the DFT B3LYP:6-31G(d.p) optimized geometries. "See the footnotes of Table 1 . 
Table 4. DFT B3LYP/6-31+G(d,p) Complexation Energies of Difterent Complexes of Host (1) with Potassium Ion

\begin{tabular}{|c|c|c|c|c|}
\hline Binding mode ${ }^{b}$ & Figure & $E_{\text {complex }}$ & $\Delta E_{\text {complex }}$ & $\Delta E_{r 2 l}$ \\
\hline $1_{\text {(ang) }} \mathrm{K}^{\prime}(c r)$ & Fig. $l(c)$ & -3654.02322 & -60.72 & 0.00 \\
\hline $1_{(a, n)} \cdot K^{+}(b z)$ & Fig. l(d) & -3654.01947 & -58.36 & 2.35 \\
\hline $1_{(\mathrm{g} p)} \cdot \mathrm{K}^{+}(c r)$ & Fig. 2(c) & -3654.01969 & -58.50 & 2.21 \\
\hline $1_{(\mathrm{f})} \cdot \mathrm{K}^{+}(b z)$ & Fig. 2(d) & -3654.01775 & -57.28 & 3.43 \\
\hline
\end{tabular}

"See the tootnotes of the Tables 2 and 3.

we would rather believe the $\mathrm{B} 3 \mathrm{LYP} / 6-3 \mathrm{I}+\mathrm{G}(\mathrm{d}, \mathrm{p})$ values. since this computational method is higher level with diffuse functions which are important for molecules with lone pairs like the host (1), and $\mathbf{1}_{(\mathrm{con})} \cdot \mathrm{K}^{+}(c r)$ conplex has more cationoxygen interactions than three other conformational analogues.

The MP2 $/ 6-311+\mathrm{G}^{*}$ calculations suggest that cationoxygen binding energy is $-19.4 \mathrm{kcal} / \mathrm{mol}$ when $\mathrm{K}^{-}$is binding to the anisole oxygen. and that cation- $\pi$ interaction energy is $-18.7 \mathrm{kcal} / \mathrm{mol}$ for $\mathrm{K}^{-}$with the benzene ring of anisole. ${ }^{9.16}$ These values tell us one reason why the $b z$-mode complexes have similar stability compared with the $(\%$-complexes.

Figure I(a) shows the front and side views of the cone_o conformation of the host 1 . Both of the methoxy groups in Figure l(a) are pointing outward. Figure l(b) displays the cone_oi conformation. in which one of the two methoxy

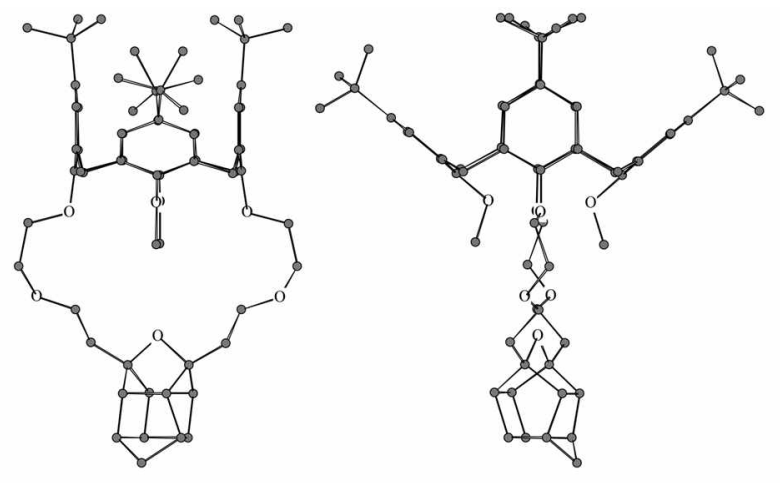

(a) $\mathbf{1}_{\text {(cone_oo) }}($ Chem3D)
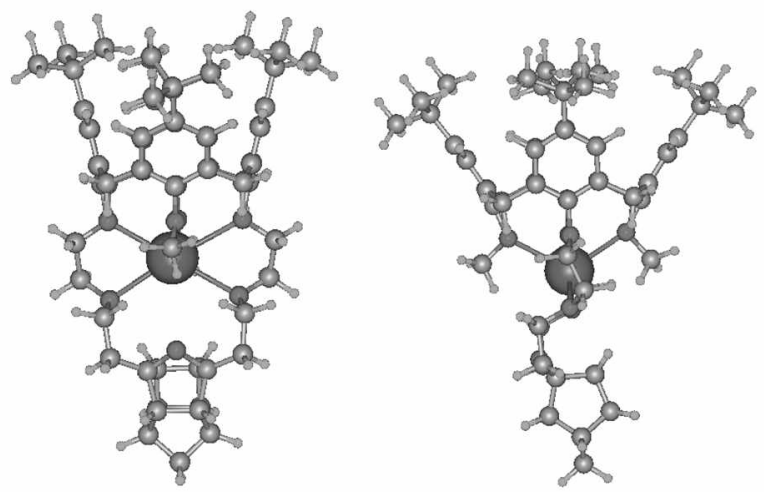

(c) $\mathbf{1}_{\text {(cone) }} \cdot \mathrm{K}^{+}($cr $)(\mathrm{PosMol})$ groups is pointing inside of the host molecule. AMl semiempirical calculated energies of both confonmers (Figures l(a) and (b)) were very similar. and so we have chosen both confomers for the $D F T$ calculation. However, as we see the values in Tables 1 and 3, the cone_oo optimized structure is proven to be more stable than the cone_oi conformer in $\mathrm{DFI}$ calculation.

Figure $\mathrm{I}(\mathrm{c})$ displays the front and side views of the potassium-ion complex in $\mathrm{cr}$-mode of the cone conformation of 1 . Atoms that are within a certain distance (the bond proximate distance) from one another were automatically marked as bonded ${ }^{1+15}$ All of oxygen atoms in the cromilether moiety in Figure $I(c)$ are converged to the potassium cation showing multiple cation-oxygen interactions. Figure l(d) shows the potassium-ion complex in $b z$-mode of the cone confonmation of 1 . When one sees the left-side view of the Figure I(d). two tent-butylbenzyl groups in the calix[4]arene moiety are vertically coordinated with the potassium ion due to the strong cation- $\pi$ interactions. Right-side view of the cone $b z$-complex displays the two more cation-oxygen interactions from potassium ion to the oxygen atoms of two anisole groups. This may be another reason for the good stability of the $b z$-complex.

Figure 2(a) shows the front and side views of the partialcone_oo conformation of the host 1 . Both of the methosy groups in Figure $\mathrm{l}(\mathrm{a})$ are pointing outward. Figure 2(b)



(b) $\mathbf{1}_{\text {(cone_oi) }}($ Chem3D)
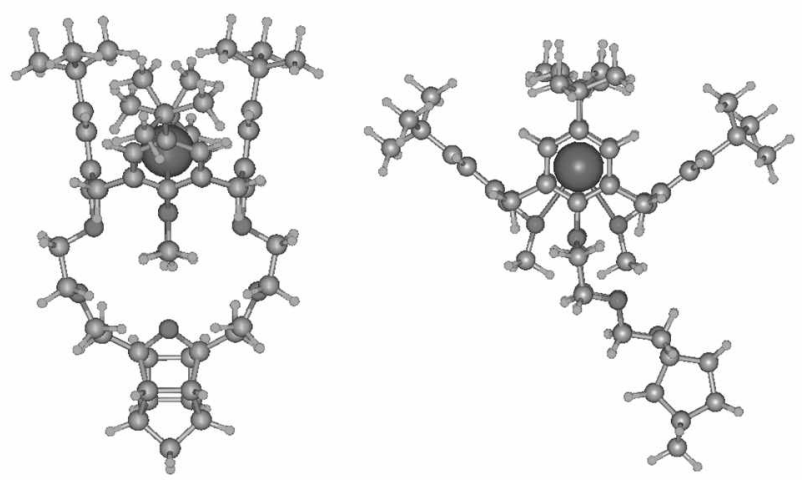

(d) $\mathbf{1}_{\text {(cone) }} \cdot \mathrm{K}^{+}(b z)$ (PosMol)

Figure 1. Front and side views of DFT B3LYP/6-31G(d,p) optimized structures of the cone conformer of 1 . (a) $1_{1 \text { sirm_on }}$ (Chem $3 \mathrm{D}^{14}$ with no

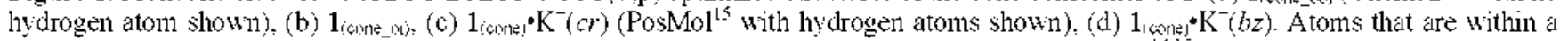
certain distance (the bond provimate distance) from one another were automatically marked as bonded. ${ }^{1.15}$ 

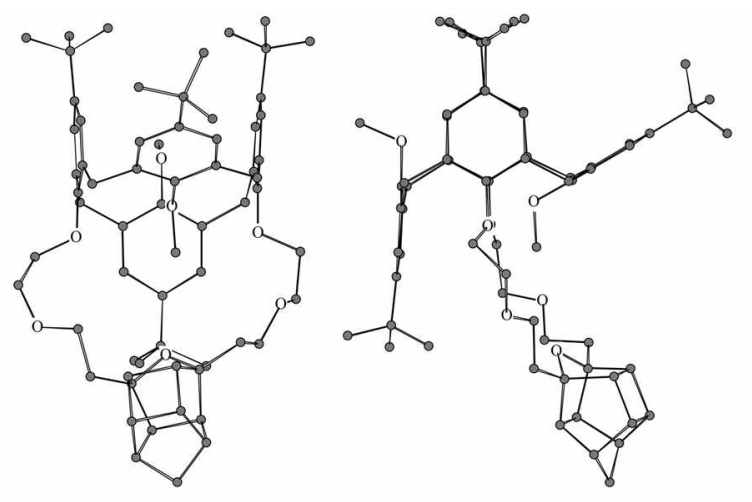

(a) $\mathbf{1}_{\left(\mathrm{pc} \_ \text {oo }\right)}($ Chem3D)
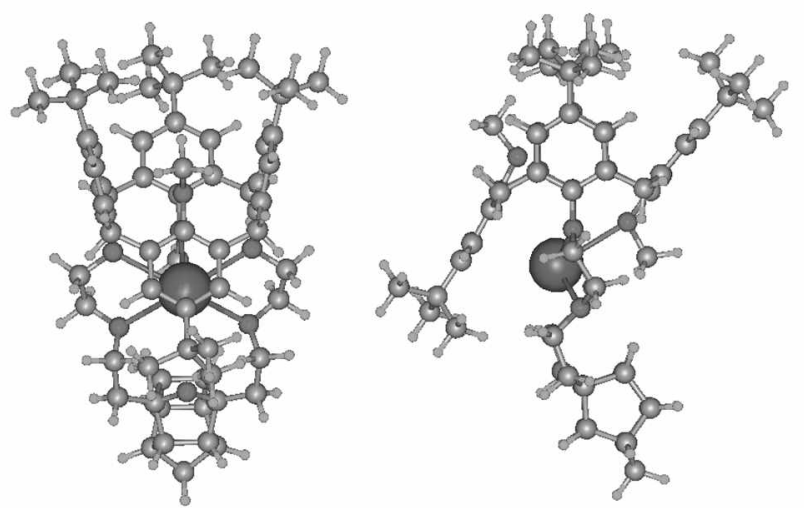

(c) $\mathbf{1}_{(\mathrm{pc})} \cdot \mathrm{K}^{+}(\mathrm{cr})(\mathrm{PosMol})$
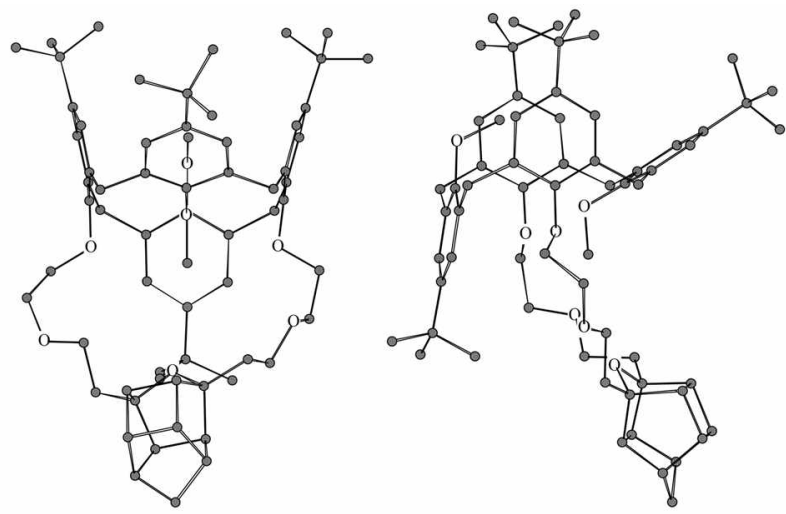

(b) $\mathbf{1}_{\text {(pc_oi) }}($ Chem3D)
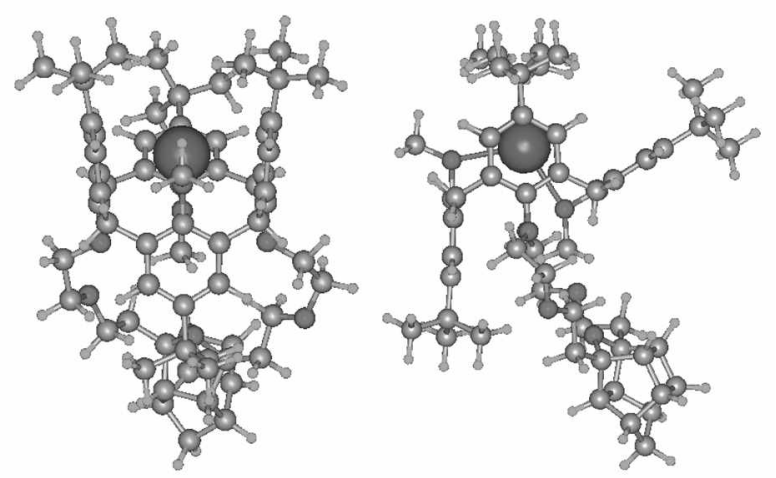

(d) $\mathbf{1}_{(\mathrm{pc})} \cdot \mathrm{K}^{+}(b z)(\mathrm{PosMol})$

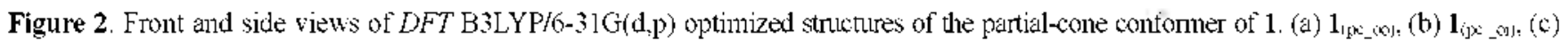
$1_{i j \times} \cdot \mathrm{K}^{+}\left(\right.$cr) , and $(\mathrm{d}) 1_{(\mathrm{j} x)} \cdot \mathrm{K}^{+}(b z)$

shows the partial-cone_oi conformation, in which one of the two methoxy groups is pointing inside of the host molecule. Figure 2(c) displays the potassium-ion complexes in $\mathrm{c} \%$ mode of the partial-cone conformation of 1 . All of oxygen atoms in the crown-ether moiety in Figure 2(c) are converged to the potassium cation showing multiple cation-oxygen interactions. Figure 2(d) shows the potassium-ion complexes in $b z$-mode of the partial-cone confomation of 1 . Right-side view of the partial-cone complex display's the two more cation-oxygen interactions from potassium ion to the oxygen atoms of two anisole groups as we observe the similar interactions in cone conformer.

To explain the cation-oxygen interactions and the relative binding efficiencies of the different complexes. we have measured the distances from the potassium cation to the oxygen atoms of the host 1 .

An interesting fact deduced from the Table 5 is that the distance $(2.60-2.79 \mathrm{~A})$ between $\mathrm{K}^{-}$and the methosy oxygen atoms of host is about $0.15 \AA$ shorter than the values $(2.74$ $2.96 \mathrm{~A}$ ) between $\mathrm{K}^{-}$and the ether-oxygen atoms of the host. These cation-oxy gen distances suggest that the electrostatic attraction between $\mathrm{K}^{-}$and the methoxy-oxygen is stronger than the ether-oxy gen atonss. since the movement of methoxy-oxygen atom is relatively free compared to the oxygen atoms of the crown-ether framework. However the oxa-
Table 5. DFT B3LYP/6-3IG(d,p) Optimized Distances $(\AA)$ between $\mathrm{K}^{+}$and the Oxygen Atoms of Host (1)

\begin{tabular}{|c|c|c|c|c|}
\hline & \multicolumn{2}{|c|}{ cr-Complex } & \multicolumn{2}{|c|}{$b z-C o n t p l e x$} \\
\hline Distance from $\mathrm{K}^{-}$ & $\mathbf{1}_{\text {coute }} \mathrm{K}^{-}$ & $\mathbf{1}_{\mathrm{ipj}} \cdot \mathrm{K}^{-}$ & $1_{\text {isule }} \cdot \mathrm{K}^{+}$ & $\mathbf{1}_{i \mathrm{p} \mathrm{i})} \cdot \mathrm{K}^{+}$ \\
\hline Ether-Oxygen (1) & 2.735 & 2.877 & & \\
\hline Ether-Oxygen (2) & 2.779 & 2.9012 & & \\
\hline Oxahexacyclic-Osygen $(3)^{a}$ & 3.657 & 3.782 & & \\
\hline Ether-Oxygen (4) & 2.825 & 2.867 & & \\
\hline Ether-Oxygen (5) & 2.965 & 2.808 & & \\
\hline Methoxy Osygen (1) & 2.681 & 2.964 & 2.787 & 2.673 \\
\hline Methoxy Osygen (2) & 2.702 & & 2.728 & 2.689 \\
\hline
\end{tabular}

${ }^{a} \mathrm{Oxygen}$ Atom of the oxahexacyclic moiety of host (1).

hexacylic-oxy'gen atom in cage-annulated moiety has much longer potassium-oxygen distance $(\sim 3.7 \mathrm{~A})$ than other $\mathrm{K}^{-}$oxygen values. and is not strongly participating cation-oxygen interaction. since the oxahexacylic group is too bulky and heavy. MP2/6-311+G* calculation suggests that the optimized binding distance between $\mathrm{K}^{-}$and the oxygen atom of an anisole is $2.617 \mathrm{~A}^{16}$

Overall, the DFT B3LYP/6-3I+G(d.p)/B3LYP/6-3IG (d.p) calculated complexation energies $(-58 \sim-68 \mathrm{kcal} / \mathrm{mol})$ of the complexes $\left(1 \cdot \mathrm{K}^{+}\right)$suggest that cage-annulated $p$-tertbutylcalix[4]arene (1) gives moderate binding efficiency 
toward to potassium ion compared with other sinilar hosts such as $2^{10}(-61 \sim-82 \mathrm{kcal} / \mathrm{mol}) .3^{6}$ and $f^{7}(-50 \sim-73 \mathrm{kcal} /$ mol).

\section{Conclusion}

B3LYP/6-3l+G(d.p)/B3LYP/6-3lG(d,p) calculations suggest that the partial-cone conformer of 1 has similar stability with the cone conformer. The binding efficiencies of potassium cation in the benzene-rings ( $b z$ ) pocket of 1 are slightly better than the values of the crown-ether $(c r)$ moiety in 1 for B3LYP/6-3lG(d.p) method. However. $1_{\text {cone) }} \mathrm{K}^{+}(c r)$ conplex showed lower single-point energy than the $\mathbf{1}_{(c m) e} \cdot \mathrm{K}^{-}(b z), \mathbf{1}_{(p c)} \cdot \mathrm{K}^{+}(c r)$ and $\mathbf{1}_{(\mathrm{pc})} \cdot \mathrm{K}^{-}(b z)$ analogues for $\mathrm{B} 3 \mathrm{LYP} / 6-3 \mathrm{l}+\mathrm{G}(\mathrm{d} . \mathrm{p})$ calculation method.

The number of cation- $\pi$ and cation-oxygen interactions with potassium cation was crucial to the stability of the different confonmation of $1 \cdot \mathrm{K}^{+}$complex. The complexation of host 1 toward to potassium cation is calculated to have comparable binding efficiencies with the 1,3-dialkyl ether of p-tert-butylcalix[4]crown-5-ether.

Acknowledgments. This research was supported by the Postdoctoral Research Program of Chung-Ang University 2006-2007 year. The large portions of the computations were carried out with use of the computer facilities at the Research Center for Computational Science of The Okazaki National Research Institutes in Japan.

\section{References}

1. (a) Ikeda. A.: Shinkai. S. Chem. Rev: 1997.97. 1713 and references cited therein. (b) Golmann. H.: Vogt. W: Paulus. E.: Böhmer. V. $J$. Am. Chem Soc. 1988. 110.6811. (c) Arduini. A.: Cantoni. M: Graviani. E: Pochini, A: Secchi, A.: Sicuri. A. R.: Ungaro. R: Vincenti. M. Tetrahedron 1995. 51, 599. (d) King, A. M.: Moore. C. P.: Sandanayake. K. R. A. S.: Sutherland. I. O. J. Chem. Soc. Chem. Conmmin. 1992. 582. (e) Gutsche. C. D. Colixarenes Revisited. Royal Society of Chemistry: Cambridge. 1998. (t) Calixarenes in Action: Mandolini. L.: Ungaro. R.. Eds.: World Scientific Publishers Co.: Singapore, 2007.

2. (a) Annaud-Nell. F.: Barrett, G.: Harris, S, J: Owens, M.: McKerver: M. A.: Schwing-Weill. M. I.: Schwinte. R. horg. Chem. 1993. 32. 2644. (b) Ghidini. E.: Ugozzoli. F.: Ungaro. R: Harkema. S.: Abu El-Fadl. A.: Reinhoudt. D. N. J. Am. Chem. Soc. 1990. 112. 6979. (c) Shinkai. S.: Otsuka. T.: Fugimoto. K: Matsuda. T. Chem. Lett. 1990, 835. (d) Gation Binding by
Macrocvcles: Inone. Y.. Gokel. G. W. Eds.: Marcel Dekker: New York. 1990. (e) Contutational Approaches in Suprantoleculor Chemisny Wiptt. G. Ed.: Kluwar Academic Publishers: Dordrecht. The Netherlands. 1994. (f) Tan, L. V: Quang. D. T.: Lee. M. H; Kim. T. H.: Kim. H.: Kim, J. S. Bull Korean Chem. Soc. 2007. 28. 79l. (g) Jeon, Y.-M; Lim. T.-H.: Kim. J.-G; Kim, J.-S.; Gong. M.-S. Bull. Korean Chent. Soc. 2007. 28.816

3. (a) Dijkstra. P. J.: Brunink. J.: Bugge. K.-E.: Reinhoudt. D. N.: Harkema. S.: Ungaro. R.: Ugozzoli. F.: Ghidini. E. J. Am. Chent. Soc. 1989. 111.7567. (b) Van Loon. J.-D.: Arduini, A.; Verboom W.: Ungaro. R.: van Hummel. G. J: Harkema. S.; Reinhoudt. D. N. Tetrahedron Lett. 1989. 30,2681.

4. Reithoudt. D. N.: Dijkstra. P. T.: in t Veld. P. T. A.: Bugge. K.-E.: Harkema. S.: Ungaro. R.: Ghidini. E. J. Ant. Chent. Soc. 1987. 109. 4761 .

5. Choe. J.-I.: Oh, D.-S. Bull Korean Chem. Soc. 2004. 25.847.

6. Choe. J.-I.: Chang S.-K.: Lee. S.; Nanbu, S. J. Hol. Sortct. (Theochem 2005. 722, 117.

7. Choe T.-I. Bull Korean Chem. Soc. 2007. 28. 235.

8. Marchand. A. P.: Chong. H.-S.: Takhi. M.: Power. T. D. Tetrahedron $2000,56.3121$

9. Nicholas, J. B.; Hay, B. P. J. Phus. Chem. A 1999, 103. 9815.

10. Choe. J.-I. Bull. Korean Chem. Soc. 2007. 28. 2130.

11. HyperChem Release 7.5; Hypercube. Ine: Waterloo, Ontario. Can1ada. 2002

12. Choe. T.-I.: Kim. K.: Chang. S.-K. Bull Korem Chen. Soc. 2000. 21. 465 .

13. Frisch, M. J.: Trucks, G. W.: Schlegel, H. B.: Scuseria, G. E.: Robb, M. A.: Cheeseman. J. R.: Zakrzewski. V. G.; Montgomery. J. A. Jr: Stratmann, R. E.: Burant, J. C.: Dapprich, S.: Millam. J. M. Daniels. A. D.: Kudin. K. N.: Strain. M. C.: Farkas. O.: Tomasi. J.: Barone. V: Cossi. M.: Cammi. R.: Mennucei. B.: Pomelli. C.: Adamo. C.: Clifford. S.: Ochtershi. T.: Petersson. G. A.: Ayala. P. Y: Cui. Q.; Morokuma. K.: Malick, D. K.; Rabuck, A. D: Raghavachari, K; Foresman, J. B.: Cioslowski. J.: Ortiz. J. V: Baboul. A. G.; Stefanov. B. B.: Liu. G.; Liashenko. A.; Piskiorz. P: Komaromi. I.: Gomperts. R.: Martin. R. L.: Fox. D. J.: Keith. I.: Al-Laham. M. A.: Peng. C. Y.: Nanayakkira. A.: Challacombe. M.: Gill. P. M. W.: John1sont. B.: Chen. W.: Wong. M. W.: Andres. J. L.; Gonzalez. C.: Head-Gordon, M.: Replogle, E. S.; Pople. J. A. Gaussian 98. Revision A.11.3; Gaussian, Inc.: Pittsburgh. PA. 1998.

14. Chent3D. Version 7.0: Cambridge Soft: Cambridge. MA. U.S.A.. 2001 .

15. Lee. S. I: Kim. K. S. POSM TOL Molecular Viewer: Pohang University of Science and Technology: Korea. 1999.

16. (a) Kim, K. S.: Tarakeshwar, P.: Lee, J. Y. Plys. Rev 2000. 100. 4145. (b) Kim, D.: Hu, S.; Tarakeshwar. P.: Kim, K. S.: Lisy. J. M. J. Phus Chem A 2003. 107. 1228. (c) Lee. T. Y.: Lee. S. J: Choi. H. S.: Cho. S. J.: Kim. K. S.: Ha. T. K. Chem. Pho Lett 1995. 232. 67. (d) Kim. K. S.: Lee. T. Y.: Lee. S. J.: Ha. T. K.: Kim. D. H. J. Am. Chem. Soc. 1994. 116.7399. 